\title{
WPŁYW POLITYKI KADROWEJ NA ZARZĄDZANIE INFORMACJĄ W TELEWIZJI PUBLICZNEJ. STUDIUM PRZYPADKU WIADOMOŚCI TVP1
}

\author{
Abstract \\ THE IMPACT PERSONNEL POLICY ON INFORMATION MANAGEMENT IN \\ THE PUBLIC TELEVISION. WIADOMOŚCI TVP1 - CASE STUDY
}

The paper is an analysis of the impact of human resources policy on information management in the main news broadcast of the first channel of the Polish Television. This article introduces the reader to the issue of human resources policy in the public media with the background of personal changes in the Polish Television after the change of power as a result of the parliamentary elections in 2015 and the impact of these changes on the way that political news are structured. In the empirical part, selected materials presented in Wiadomości, before and after the personnel reconstruction in Polish Television were examined. Using the Case Study as one of the basic ways of conducting qualitative research in humanistic management and the analysis of the content of audiovisual materials, the following events were analyzed: 11.01.2015 - XXIII Finale of the Wielka Orkiestra Świątecznej Pomocy; 12. and 19.12.2015 - crisis around the Constitutional Court and demonstrations of the KOD (Komitet Obrony Demokracji/the Committee for the Defence of Democracy); 13.12.2016 - manifestations of the KOD on the 35th anniversary of the impose of martial law; 15.01.2017 - XXV Finale of the Wielka Orkiestra Świątecznej Pomocy. The research conducted in an objective and free of author's interpretation way, leaves the reader with the opportunity of an individual reflection on changes in the ways that selected materials were presented.

Key words: government, human resources policy, information management, media organization, Polish Television

\section{Wstęp}

Analizując rynek medialny, Alan B. Albarran stwierdził, że najważniejszymi dobrami organizacji medialnych są pracownicy, a powodzenie samych mediów uwarunkowane jest umiejętnym ich pozyskiwaniem, przygotowywaniem, 
wdrażaniem i wynagradzaniem, przy jednoczesnym zagwarantowaniu właściwych warunków pracy ${ }^{1}$. To ludzie są twórcami produktów medialnych, które z kolei uzależnione są od ich kreatywności i talentu². Rynek mediów charakteryzuje się istnieniem poziomych, elastycznych struktur, przez które rozumie się możliwość podejmowania przez pracowników w razie potrzeby kilku zadań i obejmowania zróżnicowanych funkcji w tym samym czasie ${ }^{3}$. Jak pisze Alicja Sajkiewicz: „Elastyczność zasobów ludzkich jest najczęściej interpretowana jako zdolność adaptacyjna pozwalająca dostosować wielkość i strukturę zatrudnienia do zmieniających się potrzeb organizacji. Rzadziej jest dostrzegany szerszy kontekst elastyczności zasobów ludzkich, który uwzględnia nie tylko aspekt ilościowy, ale także jakościowy"4. Ma on odzwierciedlenie w sposobie wykorzystania przez pracowników swojej wiedzy i umiejętności do osiągania określonych celów oraz wypełniania standardów wynikających z pełnionych przez nich funkcji ${ }^{5}$.

Inną cechą przedsiębiorstw medialnych jest występowanie wielu zróżnicowanych profesji zawodowych, a także świadomość wagi czasu niezbędnego do zdobycia odpowiednich kwalifikacji i umiejętności ${ }^{6}$. Przygotowywanie produktu medialnego jest procesem wymagającym szczególnej intensyfikacji kreatywności i zdyscyplinowania, dlatego też w produkcji bierze udział cały szereg twórców oraz pracowników pomocniczych (np. kierowników produkcji, techników itp.). W mediach nawet najwięksi artyści nie działają na własną rękę̧.

Niewątpliwie kluczowy udział w twórczym procesie medialnym mają dziennikarze. Dziennikarstwo należące do kategorii zawodów twórczych przynosi ze sobą z jednej strony zadania wymagające kreatywności, z drugiej jednak jest nieustannie narażone na naciski rynkowe i dążenia organizacji do wzrostu słupków popularności i sprzedaży ${ }^{8}$. Właśnie tę dychotomię obrazowała postawa Ryszarda Kapuścińskiego, który powtarzał, że jest dziennikarzem, a nie pracownikiem mediów ${ }^{9}$. Z tego względu uzasadnione wydaje się twierdzenie, że o sukcesach i porażkach pracowników mediów decydują przede wszystkim ich własne postawy i zachowania ${ }^{10}$.

1 A.B. Albarran, Management of Electronic and Digital Media, Wadsworth Thomson Learning, Belmont, CA 2002, s. 123.

${ }^{2}$ M. Różycka, Zarzadzanie zasobami ludzkimi w mediach publicznych. Studium przypadku TVP Katowice, „Zarządzanie Mediami” 2016, nr 4 (2), s. 70.

3 Tamże.

${ }^{4}$ A. Sajkiewicz (red.), Jakość zasobów pracy. Kultura, kompetencje, konkurencyjność, Poltext, Warszawa 2002, s. 100-101.

5 Tamże.

${ }^{6}$ A.K. Koźmiński, W. Piotrowski (red.), Zarządzanie. Teoria i praktyka, Wydawnictwo Naukowe PWN, Warszawa 1997, s. 363-369.

${ }^{7}$ M. Różycka, dz. cyt., s. 71.

8 Tamże.

${ }^{9}$ B. Nierenberg, Zarządzanie mediami. Ujęcie systemowe, Wydawnictwo Uniwersytetu Jagiellońskiego, Kraków 2011, s. 39.

${ }^{10}$ M. Różycka, dz. cyt., s. 71. 
Współczesne zarządzanie zasobami ludzkimi opiera się w głównej mierze na umiejętności dokonania właściwej oceny potencjału, predyspozycji i umiejętności pracownika, a następnie zastosowania ich w praktyce dla osiągnięcia pożądanych celów organizacji ${ }^{11}$. Obserwując firmy medialne, można jednak zauważyć trend idący nie w stronę zwiększania, ale ograniczania zatrudnienia. Jean Brilman słusznie podkreśla, że „dla mediów coraz bardziej charakterystyczna jest praca czasowa lub współpraca, a nie zatrudnienie na etat. Firmy preferują kontrakty terminowe i nie dają gwarancji zatrudnienia w dłuższym czasie. Coraz częściej mówi się o zdolności do bycia zatrudnionym aniżeli o zatrudnieniu"12.

Przeprowadzane w mediach zmiany strukturalne odbywają się na wielu płaszczyznach, poczynając od metod i narzędzi pracy, przez wzajemne relacje międzyludzkie i podział obowiązków, a na procesach decyzyjnych kończąc. W przypadku przedsiębiorstw medialnych objawia się to poprzez wyłanianie redakcji, obsadzanie stanowisk kierowniczych oraz formułowanie zasad dotyczących klasyfikowania ${ }^{13}$. Nieodpowiednia reorganizacja może skutkować osłabieniem zaangażowania osób biorących udział w twórczym procesie powstawania produktu medialnego, tym samym przyczyniając się do obniżenia jego jakości, będącej kluczowym elementem w dążeniu do przewagi konkurencyjnej firmy medialnej ${ }^{14}$.

Pozostając przy kwestii przewagi konkurencyjnej, warto przywołać myśl Roberta G. Picarda, zgodnie z którą media istnieją na dwóch równoległych rynkach. Zjawisko to określane jest przez autora jako dual product market ${ }^{15}$. Rynek mediów skupia się głównie na kwestiach związanych z wartością użytkową, czyli poziomem zaspokojenia potrzeb informacyjnych i rozrywkowych odbiorców. Wartość użytkową determinuje przede wszystkim treść wypływająca $z$ danego medium, która jest wynikiem wspólnej pracy twórczej, wykonywanej przez wielu specjalistów z różnych dziedzin. Drugim rynkiem, o którym mówi autor, jest rynek reklamy, nieustannie zyskujący na znaczeniu dla branży medialnej. Rynek ten charakteryzuje się współpracą mediów z reklamodawcami w zakresie pośrednictwa mediów w procesie komunikowania pomiędzy reklamodawcami a odbiorcami ${ }^{16}$. Ta właśnie zdolność ma dziś zasadnicze znaczenie dla firmy medialnej na drodze do sukcesu rynkowego ${ }^{17}$.

Jednym $\mathrm{z}$ najistotniejszych elementów mających wpływ na funkcjonowanie organizacji medialnej jest sposób sprawowania władzy przez jej właściciela ${ }^{18}$.

11 Tamże.

12 J. Brilman, Nowoczesne koncepcje i metody zarządzania, przeł. K. Bolesta-Kukułka, PWE, Warszawa 2002, s. 343.

13 T. Kowalski, Między twórczością a biznesem, Wydawnictwa Akademickie i Profesjonalne, Warszawa 2008, s. 55.

${ }^{14}$ M. Różycka, dz. cyt., s. 71.

15 R.G. Picard, Media Economics: Concepts and Issues, Sage Publications, Thousand Oaks, CA 1989, s. 17.

16 Tamże.

${ }_{17}$ M. Różycka, dz. cyt., s. 72.

18 Tamże. 
Zarządzający mniejszymi firmami medialnymi mogą kierować nimi lub kontrolować je w sposób bezpośredni ${ }^{19}$, co pozwala im aktywnie zarządzać firmą i szybko reagować na fluktuacje rynkowe. Powiększanie obszaru oddziaływania instytucji medialnej oraz rozwój jej struktury organizacyjnej wymaga jednak zmiany sposobu kierowania $\mathrm{w}$ stronę bardziej pośredniego ${ }^{20}$. Odmiennie niż w przypadku mediów komercyjnych, nastawionych głównie na zysk, media publiczne muszą umieć równoważyć cele ekonomiczne z ideałami misyjności i służby publicznej, a często także z polityką rządzących ${ }^{21}$.

Przedsiębiorstwa medialne, $\mathrm{w}$ tym również nadawcy publiczni, funkcjonują na rynku konkurencyjnym. W efekcie na znaczeniu zyskują czynniki związane $\mathrm{z}$ reputacją, prestiżem oraz zasobami personalnymi, na czele $\mathrm{z}$ liderami opinii i celebrytami. Wydaje się, że to właśnie zasoby ludzkie mogą odgrywać tu główną rolę ${ }^{22}$. Nie ulega zatem wątpliwości, że kluczowe dla organizacji medialnej jest stworzenie profesjonalnego zespołu, w którym każda jednostkowa działalność będzie istotnym elementem całościowej medialnej układanki. Dlatego tak ważne jest, aby zarówno $\mathrm{w}$ tradycyjnym, jak i medialnym biznesie „każde zadanie orientować na cele całości (...)"23.

Tadeusz Kowalski zauważa, że sukces organizacji medialnych jest zależny od pracy ludzi utalentowanych ${ }^{24}$. W perspektywie zarządzania można wyróżnić dwa nieantagonistyczne wobec siebie podejścia. Pierwsze zakłada samodzielne tworzenie talentów oraz warunków niezbędnych do ich odpowiedniego rozwoju. W ten sposób funkcjonowały publiczne przedsiębiorstwa medialne, które oferując pracę pełnoetatową lub opartą na długotrwałym kontrakcie, gwarantowały pracownikom poczucie stabilizacji, a jednocześnie cementowały współpracę z najzdolniejszymi twórcami (np. Wojciech Mann, Monika Olejnik). Drugie podejście reprezentowane jest przez media komercyjne, dla których posiadanie talentów stanowi wartość najwyższą. Opiera się ono z jednej strony na inwestowaniu w nowe twarze (np. Justyna Pochanke, Dorota Gawryluk), a z drugiej na werbowaniu talentów z firm konkurencyjnych ${ }^{25}$.

W przeszłości często dochodziło do różnorodnych zmian organizacyjnych w Telewizji Polskiej, uwarunkowanych zarówno potrzebami tego przedsiębiorstwa, jak i wpływami natury politycznej. Obserwując jednak bieżące wydarzenia na polskiej scenie polityczno-medialnej, można pokusić się o stwierdzenie, że żadne z podjętych wcześniej decyzji reorganizacyjnych nie miały tak dużego wymiaru,

${ }_{19}$ M. Mrozowska, Media masowe. Władza, rozrywka i biznes, Oficyna Wydawnicza ASPRA-JR, Warszawa 2001, s. 239.

20 Tamże, s. 240.

${ }^{21}$ Tamże.

${ }^{22}$ M. Różycka, dz. cyt., s. 74.

${ }^{23}$ P.F. Drucker, Praktyka zarządzania, przeł. T. Basiuk, Z. Broniarek, J. Gołębiowski, Wydawnictwo MT Biznes, Warszawa 2008, s. 232, cyt. za: M. Różycka, dz. cyt., s. 74.

${ }^{24}$ T. Kowalski, dz. cyt., s. 99.

25 Tamże. 
jak w przypadku rewolucji kadrowej w TVP po wyborach parlamentarnych w 2015 roku, kiedy to Prawo i Sprawiedliwość uzyskało liczbę mandatów umożliwiającą samodzielne rządzenie.

\section{Zmiany kadrowe w TVP po objęciu władzy przez Prawo i Sprawiedliwość}

\subsection{Zmiany na stanowiskach kierowniczych i masowe zwolnienia}

Rewolucja kadrowa w Telewizji Polskiej rozpoczęła się w styczniu 2016 roku, po objęciu stanowiska prezesa TVP przez Jacka Kurskiego. Członkiem zarządu został wcześniej Maciej Stanecki. Wymieniono wtedy też dyrektorów najważniejszych anten i wybrano nowego dyrektora Telewizyjnej Agencji Informacyjnej - organu nadzorczego wobec wszystkich programów informacyjnych TVP1, TVP2 oraz TVP Info, którym został Mariusz Pilis ${ }^{26}$.

Prawdziwe trzęsienie ziemi nastąpiło jednak w redakcji Wiadomości. 11 stycznia 2016 roku był dniem, w którym rozpoczęła się tam fala masowych zwolnień. Pierwszą ofiarą rewolucji kadrowej stał się Piotr Kraśko. Po tym, jak ostatni raz poprowadził główne wydanie Wiadomości, z ust Jacka Kurskiego miały wobec niego paść słowa, iż Wiadomości mogą być dobre albo złe, ale muszą być uczciwe ${ }^{27}$. W dzień odejścia Kraśko umieścił na swoim profilu na Twitterze wymowny wpis: „25 lat w TVP, $12 \mathrm{w}$ Wiadomościach (...) - szczęście pracy ze świetnym zespołem, 14 prezesów, piętnasty będzie ostatnim (...)"28.

Trzy dni później wypowiedzenie otrzymała Beata Tadla. Prezenterka została zwolniona z TVP po ponad trzech latach pracy. Dyrektor TAI Mariusz Pilis miał rzekomo uzasadniać swoją decyzję „zmianą koncepcji programu”. Na swoim profilu facebookowym Tadla napisała: „(...) Moje rozstanie z TVP odbyło się bardzo kulturalnie. Ot, nie pasuję do koncepcji nowych Wiadomości (...)"29. Beata Tadla była prowadzącą główne wydanie Wiadomości od listopada 2012 roku, prowadziła również program Kawa czy herbata? Kilkukrotnie pełniła funkcję gospodyni wieczoru wyborczego.

Z serwisem informacyjnym TVP1 musiało się pożegnać także czworo reporterów. Justyna Dobrosz-Oracz związana była z TVP od 2000 roku. Swoje pierwsze kroki stawiała w Teleexpressie, następnie relacjonowała dla Wiadomości wydarzenia

${ }^{26}$ Zob. http://www.wirtualnemedia.pl/artykul/wiatr-zmian-w-tvp-jacka-kurskiego-kto-odszedl-kto-przyszedl\# (dostęp: 8.04.2017).

${ }_{27}$ Zob. http://www.polskatimes.pl/artykul/9280595,piotr-krasko-i-karolina-lewicka-odchodza-z-tvp-beata-tadla-i-diana-rudnik-odsuniete-od-wiadomosci,id,t.html (dostęp: 8.04.2017).

${ }_{28}$ Zob. https://twitter.com/pkrasko (dostęp: 8.04.2017).

${ }^{29}$ Zob. https://www.facebook.com/beata.tadla.3/posts/1201382883211217 (dostęp: 8.04.2017). 
z polskiej sceny politycznej. Była również prowadzącą poranny program Polityka przy kawie. Elżbieta Byszewska z kolei była odpowiedzialna za przygotowywanie dla Wiadomości materiałów o tematyce medycznej i społecznej. Pełniła ponadto funkcję wydawcy porannych, południowych i popołudniowych wydań serwisu. Milena Kruszniewska zajmowała się relacjonowaniem wydarzeń zagranicznych, a Jacek Tacik przygotowywał materiały na temat wydarzeń zarówno z kraju, jak i zagranicy.

Niewątpliwie dużym zaskoczeniem było odejście z Telewizji Polskiej Macieja Orłosia. Sprawa zyskała duży rozgłos w mediach społecznościowych, gdzie swoje poparcie dla niego wyrażali inni dziennikarze ${ }^{30}$. Znany od wielu lat $\mathrm{z}$ prześmiewczych ciekawostek opowiadanych tuż przed zakończeniem Teleexpressu, dziennikarz osobiście pożegnał się z widzami podczas swojego ostatniego wydania. Orłoś był w TVP postacią niemal ikoniczną. Przez 25 lat był gospodarzem Teleexpressu, prowadził też takie programy jak Kawa czy herbata? oraz teleturniej 300 procent normy. Wielokrotnie wcielał się w rolę konferansjera przy okazji różnych festiwali i koncertów ${ }^{31}$.

Również na antenie TVP Info doszło do istotnych zmian personalnych. Po 23 latach pracy pokład Telewizji Polskiej opuściła Joanna Osińska. Dziennikarka pracowała w TVP Info (wcześniej TVP3) przez kilkanaście lat. Była gospodynią programu Minęła dwudziesta oraz serwisów informacyjnych. Przez 20 lat współpracowała też z TVP Szczecin, gdzie prowadziła program informacyjny Kronika, a także programy Gość dnia, Gość Trójki i Obraz dnia. Ponadto była związana z TVP1, TVP2 i TVP Polonia ${ }^{32}$.

Jedną z najbardziej kontrowersyjnych dziennikarek, których odejście z TVP odbiło się szerokim echem, była Karolina Lewicka. Kontrowersje wokół jej osoby nasiliły się pod koniec listopada 2015 roku, kiedy w programie Minęła dwudziesta przeprowadziła burzliwy wywiad z ministrem kultury, prof. Piotrem Glińskim. W konsekwencji została przez prezesa TVP odsunięta od roli gospodarza programu na okres ponad tygodnia. Komisja Etyki TVP stwierdziła jednak później, że nie doszło do naruszenia przez Lewicką standardów zawodowych. Kolejne oskarżenia o stronniczość padły w stronę dziennikarki w połowie grudnia 2015 roku, niedługo po pierwszym marszu Komitetu Obrony Demokracji i marszu poparcia dla rządu i prezydenta. Lewicka była odpowiedzialna za przygotowanie materiału na ten temat dla Wiadomości. Niektórzy dziennikarze uznali go za jednostronny, a posłanka PiS Joanna Lichocka odmówiła rozmowy z dziennikarką, nazywając ją propagandystką. Ostatecznie Lewicka zdecydowała się (chcąc zapewne uprzedzić zwolnienie) na

${ }^{30}$ Zob. http://businessinsider.com.pl/media/maciej-orlos-odchodzi-z-teleexpressu-tvp/wy4lh4j (dostęp: 8.04.2017).

${ }_{31}$ Zob. http://businessinsider.com.pl/media/maciej-orlos-odchodzi-z-teleexpressu-tvp/wy4lh4j (dostęp: 8.04.2017).

${ }_{32}$ Zob. http://www.wirtualnemedia.pl/artykul/joanna-osinska-po-23-latach-konczy-prace-w-telewizji-polskiej (dostęp: 8.04.2017). 
złożenie wypowiedzenia. W TVP pracowała ponad pięć lat, prowadząc w tym czasie programy publicystyczne i przygotowując materiały reporterskie ${ }^{33}$.

Do grona dziennikarek, które opuściły TVP, dołączyła także Diana Rudnik, chociaż jej sytuacja nie była na początku przesądzona. Od września 2015 roku była prowadzącą niedzielnego wydania Wiadomości i z tej funkcji została odsunięta w wyniku zmiany władz. W dalszym ciągu prowadziła programy Info Dzień oraz blok Info Poranek w TVP Info. Ostatecznie jednak po 10 latach pracy rozstała się z Telewizją Polską ${ }^{34}$.

Najmniejsza skala zmian dotyczy jak na razie Panoramy TVP2. Pojawiają się tutaj jednak dwa istotne nazwiska: Hanny Lis i Ewy Godlewskiej-Jeneralskiej. Zwolnienie Hanny Lis dyrektor Mariusz Pilis tłumaczył potrzebą odbudowy wiarygodności programów informacyjnych TVP, zapewniając jednocześnie, że jego decyzja nie wynikała z pobudek osobistych. Lis prowadziła Panoramę od 2012 roku. Kilka lat wcześniej pełniła funkcję gospodyni Wiadomości, jednak ówczesny prezes TVP Piotr Farfał rozwiązał z nią kontrakt, oskarżając ją o naruszenie zasad etyki dziennikarskiej. W przeszłości była związana również z Polsatem, TV4 i Teleexpressem ${ }^{35}$.

Ewa Godlewska-Jeneralska była z kolei producentką i wydawcą Panoramy. Pracowała na tym stanowisku 25 lat, a 30 lat w samej TVP. Zaczynała między innymi jako prezenterka Wiadomości. Na Facebooku żegnała się słowami: „(...) z dumą przyjmuję fakt, że "poległam« w tak znakomitym gronie jak Tomek Sygut, Hanna Lis, Piotr Maślak, Karolina Lewicka i jeszcze kilku innymi świetnych dziennikarzy $(. . .)^{\prime 36}$.

\subsection{Wielkie powroty i nowe nazwiska w TVP}

Stanowiska pozostawione przez zwolnionych dziennikarzy objęli głównie inni pracownicy Telewizji Polskiej, zajmujący do tej pory mniej prominentne pozycje.

Piotra Kraśkę na stanowisku szefa redakcji Wiadomości zastąpiła Marzena Paczuska, która wcześniej przez wiele lat pełniła funkcję wydawcy i wiceszefowej, a w ostatnim czasie była szeregowym pracownikiem redakcji TVP1 $1^{37}$.

${ }_{33}$ Zob. http://www.wirtualnemedia.pl/artykul/karolina-lewicka-odchodzi-z-telewizji-polskiej (dostęp: 8.04.2017).

${ }_{34}$ Zob. http://www.wirtualnemedia.pl/artykul/diana-rudnik-po-10-latach-odchodzi-z-tvp-info\# (dostęp: 8.04.2017).

${ }_{35}$ Zob. http://www.wirtualnemedia.pl/artykul/hanna-lis-zwolniona-z-panoramy-tvp2 (dostęp: 8.04.2017).

${ }^{36}$ Zob. http://wiadomosci.onet.pl/kraj/ewa-godlewska-jeneralska-zwolniona-z-tvp/dvm5n1 (dostęp: 8.04.2017).

${ }_{37}$ Zob. http://www.wirtualnemedia.pl/artykul/wiatr-zmian-w-tvp-jacka-kurskiego-kto-odszedl-kto-przyszedl\# (dostęp: 8.04.2017). 
Po sześciu latach nieobecności na antenie TVP1 do roli prowadzącej główne wydanie Wiadomości powróciła Danuta Holecka. O powrocie dziennikarki spekulowano jeszcze kilka dni przed pierwszym poprowadzonym przez nią wydaniem serwisu Jedynki. Wszelkie wątpliwości rozwiała pierwsza konferencja prasowa Jacka Kurskiego już w roli prezesa TVP, gdzie obok Anny Popek i Przemysława Babiarza pojawiła się właśnie Holecka. Ostatni raz główne wydanie Wiadomości dziennikarka prowadziła w 2010 roku. Programem kierował wtedy Jacek Karnowski, a jego zastępczynią była Marzena Paczuska. Holecką usunięto po przejęciu szefostwa nad serwisem przez Małgorzatę Wyszyńską. Wcześniej prowadziła już główny serwis TVP1 w latach 1997 oraz 2003-2004, gdy stanowisko prezesa TVP piastował Robert Kwiatkowski ${ }^{38}$. W ostatnich latach była prowadzącą serwisy informacyjne i programy publicystyczne w TVP Info. W 2013 roku przeszła do TVP Regionalnej (obecnie TVP3) ${ }^{39}$.

Do łask powrócił także Michał Adamczyk, którego rola w TVP uległa w ostatnim czasie zmniejszeniu - prowadził jedynie boczne wydania serwisu Jedynki i programów Panorama dnia czy Godzina po godzinie w TVP Info. Wcześniej główne wydania Wiadomości prowadził w latach 2003-2005 oraz 2011-2012. Był również gospodarzem Teleexpressu i korespondentem Telewizji Polskiej w Brukseli, ponadto udzielał się jako komentator wydarzeń zagranicznych w TVP Info, był gospodarzem serwisów i współprowadził sobotnie wydanie Kawy czy herbaty? w TVP1. Z Telewizją Polską związany jest od 16 lat, wcześniej pracował w TVN i TV Puls ${ }^{40}$.

Opuszczone w wyniku zwolnień stanowiska reporterskie zajęli m.in.: Jarosław Olechowski, do tej pory reporter w TVP Info, Małgorzata Wiśniewska, związana wcześniej z Panoramą, oraz Marcin Tulicki, który dotąd pracował w TVP Katowice.

Po trzech latach przerwy na antenę TVP Info w roli gospodarza programów publicystycznych powrócił Adrian Klarenbach. Powrót na antenę TVP dziennikarz ogłosił na swoim profilu na Facebooku. Klarenbach pracował w TVP Info od początku istnienia kanału w 2007 roku. Prowadził serwisy informacyjne i programy publicystyczne (m.in. Minęła dwudziesta) oraz wieczory wyborcze. W 2013 roku zniknął $z$ anteny. Przed powrotem do TVP Info pracował w Tele 5 jako prowadzący program publicystyczny Bez pardon $u^{41}$.

Do grona pracowników TVP dołączył również Klaudiusz Pobudzin, który nigdy wcześniej nie pracował dla tej organizacji. Do jego obowiązków należy przygotowywanie materiałów relacjonujących dla Wiadomości. Wcześniej był reporterem

${ }^{38}$ Zob. http://www.wirtualnemedia.pl/artykul/danuta-holecka-wraca-do-prowadzenia-wiadomosci-tvp1 (dostęp: 8.04.2017).

39 Zob. http://fakty.interia.pl/polska/news-nowe-twarze-wiadomosci,nId,1953622,nPack,1 (dostęp: 8.04.2017).

${ }^{40}$ Zob. http://www.wirtualnemedia.pl/artykul/michal-adamczyk-wraca-do-glownego-wydania-wiadomosci-tvp1 (dostęp: 8.04.2017).

${ }^{41}$ Zob. http://www.wirtualnemedia.pl/artykul/adrian-klarenbach-po-trzech-latach-wraca-do-tvp-info (dostęp: 8.04.2017). 
i prowadzącym program Polski punkt widzenia w Telewizji Trwam. Kolejnymi osobami niezwiązanymi do tej pory z TVP są m.in. Michał Rachoń, Piotr Gursztyn i Marcin Pieńkowski ${ }^{42}$.

Opisane powyżej zmiany kadrowe po objęciu stanowiska prezesa Telewizji Polskiej przez Jacka Kurskiego to jedynie najważniejsze nazwiska, które musiały pożegnać się lub powróciły do pracy w tej instytucji medialnej ${ }^{43}$. W wyniku generalnej rekonstrukcji kadrowej nastąpiła też zmiana narracji prezentowanej w głównych wydaniach Wiadomości i w TVP Info. Ostatnia część artykułu będzie traktować o zarządzaniu informacją $\mathrm{w}$ wymiarze praktycznym, biorąc pod uwagę opisany powyżej przypadek Telewizji Polskiej i na podstawie prezentowanych materiałów o charakterze politycznym w głównych wydaniach Wiadomości TVP.

\section{Wpływ rekonstrukcji kadrowej na zarządzanie informacją w głównych wydaniach Wiadomości TVP - studium przypadku ${ }^{44}$}

\subsection{Kryzys wokół Trybunału Konstytucyjnego - Manifestacje KOD ${ }^{45}$}

„Ta partia wszystko robi, żeby wprowadzić dyktaturę” - tymi słowami, wypowiedzianymi przez przypadkowego demonstranta, rozpoczyna się główne wydanie Wiadomości w dniu 12 grudnia 2015 roku. Manifestacje Komitetu Obrony Demokracji stanowiły w tym dniu temat przewodni serwisu informacyjnego TVP1. Prowadząca wydanie Beata Tadla rozpoczęła zapowiedź materiału reporterskiego od zwrócenia uwagi na wielotysięczną liczbę demonstrujących „w obronie demokracji" na ulicach polskich miast. Podała informację o szacunkowych obliczeniach stołecznego ratusza, z których wynika, że w samej Warszawie udział w marszu wzięło nawet 50 tysięcy manifestantów. Tadla podkreśliła, że była to największa w kraju manifestacja pod hasłem „niezgody na to, co robi rząd i prezydent w sprawie Trybunału Konstytucyjnego”. Prezenterka przytoczyła mocne słowa padające z ust opozycjonistów podczas manifestacji, m.in. „tu jest Polska” i „zatrzymajmy marsz szaleńców”. Swoją zapowiedź skończyła stwierdzeniem, że wśród demonstrujących w tłumie polityków zdecydowaną większość stanowili jednak „nie-politycy”. Głos zabrała Justyna Dobrosz-Oracz.

${ }^{42}$ Zob.http://www.wirtualnemedia.pl/artykul/wiatr-zmian-w-tvp-jacka-kurskiego-kto-odszedl-kto-przyszedl (dostęp: 8.04.2017).

${ }^{43}$ Zob. http://www.polskatimes.pl/artykul/9289275,kolejni-dziennikarze-zwolnieni-z-tvp-nowi-prezenterzy-zmiany-w-telewizji-kto-stracil-prace-lista,id,t.html (dostęp: 8.04.2017).

${ }^{44}$ Na podstawie materiałów archiwalnych uzyskanych od Ośrodka Dokumentacji i Zbiorów Programowych TVP.

${ }_{45}$ Źródło: główne wydania Wiadomości TVP1, 12.12.2015 i 19.12.2015. 
Na ekranie ukazała się kobieta machająca $\mathrm{z}$ balkonu do tłumu ludzi wykrzykujących hasło: „Precz z Kaczorem, dyktatorem!”. Reporterka zaczęła swój materiał słowami: „Taki ruch oporu, miesiąc po wyborach - tego w historii wolnej Polski nie było". W kadrze pojawiły się dwie dorosłe kobiety wraz z trójką dzieci, które ze wstydliwym uśmiechem i niepewnością w głosie próbowały krzyczeć: „Tu jest Polska!". Autorka materiału już na samym początku kilkakrotnie formułowała wyrażenia będące opiniami. Po pierwsze, kładła nacisk na skalę demonstracji, twierdząc, że przerosła ona oczekiwania nawet organizatorów. Nie poparła jednak tej tezy żadnymi danymi lub co najmniej wypowiedzią jednej z osób organizujących marsz. Następnie dziennikarka podkreśliła, że kilkanaście tysięcy ludzi wyszło na ulicę, aby protestować „przeciwko łamaniu konstytucji”, przy czym mówiła to w tonie sugerującym, że owo „łamanie konstytucji” rzeczywiście i niezaprzeczalnie ma miejsce. W tym samym czasie na ekranie pojawiła się grupa ludzi trzymających biało-czerwony transparent, na którym napisano: „Kraków przeprasza za: Dudę, Ziobrę i Gowina. Kraków popiera TK”. Dalej Dobrosz-Oracz podkreśliła, że wielu protestujących nie jest zrzeszonych w żadnych partiach czy organizacjach, co oczywiście może być prawdą, jednak ze względu na brak możliwości zweryfikowania tej tezy należy ją w tym kontekście również uznać za opinię. Reporterka dodała, że niektórzy maszerują pierwszy raz, a inni pierwszy raz od 1989 roku, co stanowi wyraźne nawiązanie do czasów PRL i nie jest poparte żadną konkretną wypowiedzią. W kadrze pojawił się co prawda jeden $\mathrm{z}$ protestujących (notabene ten sam, którego można było zobaczyć na samym początku serwisu), ale wypowiadał słowa zupełnie niezwiązane z kontekstem: „Czy chcemy mieć Koreę Północną, Rosję tutaj? Przecież to jest zagrożenie dla niezależności Polski”. Po chwili do grona wypowiadających się dołączyli starszy pan, który oznajmił, że w roku 1981 nieraz miał kajdanki na rękach i nie pozwoli na to, aby Polacy znów żyli w kajdankach, oraz młody chłopiec, podkreślający rolę konstytucji jako strażnika demokracji i konieczność demonstrowania, gdy ta konstytucja jest przez ,jakąś władzę" łamana.

W dalszej części materiału oczom widzów ukazali się politycy opozycji: Barbara Nowacka, Ryszard Petru, Władysław Kosiniak-Kamysz oraz Katarzyna Lubnauer, trzymający wspólnie transparent przygotowany przez Komitet Obrony Demokracji i wykrzykujący hasło: „Obronimy demokrację!” W tym samym czasie reporterka mówiła o sukcesie KOD-u, który w zaledwie trzy tygodnie od powstania zdołał zmobilizować znacznie większą liczbę ludzi, niż udało się to Platformie Obywatelskiej w czasach „IV RP” podczas tzw. błękitnego marszu. Następnie na ekranie widać było przemawiającego do tłumu Mateusza Kijowskiego, ówczesnego lidera Komitetu Obrony Demokracji, który zwracał uwagę na to, że „większość nie może dyktować innym swojego sposobu życia”. Tuż po tej wypowiedzi Justyna Dobrosz-Oracz zauważała, że zdezorientowana po wyborach opozycja zaczyna umiejętnie wykorzystywać nadarzającą się okazję do działania. Zanim jednak do głosu doszli przedstawiciele opozycji, materiał ukazał sondaż przeprowadzony dla TVP przez Ipsos, według którego 56\% ankietowanych uważa, że demokracja jest 
w Polsce zagrożona, a 37\% jest przeciwnego zdania. Następnie po kolei pokazywani byli przedstawiciele partii opozycyjnych. Petru postulował zatrzymanie „marszu szaleńców”, a Kosiniak-Kamysz mówił o konieczności odwołania się do praw podstawowych. Po tych słowach autorka materiału podkreśliła, iż kryzys wokół Trybunału Konstytucyjnego zjednoczył opozycję. Twierdziła, że poparcie dla opozycji w sondażach rośnie, jednak po raz kolejny nie zostało to poparte konkretnym przykładem. Chwilę później na ekranie pojawiła się jeszcze Barbara Nowacka, wykrzykująca wśród gromkich braw hasło: „Jarosławie Kaczyński, tu jest Polska!”.

W kolejnej części Justyna Dobrosz-Oracz po raz pierwszy przywołała stanowisko Prawa i Sprawiedliwości, mówiąc: „do tego momentu politycy PiS utrzymywali, że spór o Trybunał Polaków nie obchodzi, ale okazało się, że to nie jest abstrakcja”. Reporterka wskazała, że obrona Trybunału była tylko jednym z postulatów, a obok niego pojawia się sprzeciw wobec tempa zmian i „dyktatury większości”. Tuż po tych słowach na ekranie ukazała się postać Sławomira Neumanna, przewodniczącego klubu parlamentarnego PO, a następnie innych polityków Platformy Obywatelskiej na czele z uśmiechniętym Grzegorzem Schetyną.

Następną część materiału otwarły zdjęcia demonstrujących z kilku innych miast w kraju oraz słowa reporterki: „Trudno będzie rządzącym zbagatelizować protesty”, co również stanowi opinię. Na ekranie po raz kolejny pojawił się przypadkowy protestujący, który porównał demokrację do „powolnego gotowania żaby”. Swoją opinię ponownie przedstawiła Dobrosz-Oracz, mówiąc o nadziei protestujących na „wyhamowanie” władzy i respektowanie przez nią wyroków Trybunału.

Reporterka nie pominęła w materiale również prezydenta Andrzeja Dudy. Mówiąc o jego decyzji w kontekście podpisania nowelizacji ustawy o Trybunale Konstytucyjnym, dziennikarka stwierdziła, że koszt takiego działania „może być duży”. Po tych słowach w kadrze ukazały się tłumy skandujące pod pałacem prezydenckim hasła: „Andrzej Duda - marionetka!” czy „Andrzej Duda - oddaj dyplom!”.

Chwilę później reporterka mówiła o podziałach wśród społeczeństwa, pogłębianych przez polityczne napięcie. Na ekranie pojawiła się protestująca kobieta, która zwracała się do Jarosława Kaczyńskiego słowami: „Panie Kaczyński, pan jest nikim! Pan niszczy Polskę!”, a następnie inny demonstrujący ze łzami w oczach oznajmiający, że „prawo i konstytucja daje nam to, że istniejemy, jesteśmy narodem polskim”.

W całym opisywanym materiale nie wypowiedziała się osoba przeciwna demonstracjom lub przedstawiciel partii rządzącej. Dobrosz-Oracz wspominała jednak o zorganizowanej przez grupę narodowców pikiecie. W imieniu Ruchu Narodowego wypowiedział się Jarosław Konowałek: „Czujemy, że poprzedni system próbuje kwiczeć głośno przy odrywaniu (...) od koryta, próbuje wyprowadzać ludzi na ulice".

$\mathrm{Na}$ końcu materiału reporterka podkreśliła, że o bezpieczeństwo i porządek przez cały czas dbała policja. Zapowiedziała również mający się odbyć nazajutrz marsz zwolenników rządu. Materiał przygotowany przez Justynę Dobrosz-Oracz trwał niespełna 5 minut. 
Tydzień później, 19 grudnia 2016 roku w sumie w ponad 20 miastach w Polsce i za granicą odbyły się ponowne manifestacje zorganizowane przez Komitet Obrony Demokracji. Był to temat zajmujący pierwsze miejsce na agendzie Wiadomości, prowadzonych w tym dniu przez Krzysztofa Ziemca. Za materiał reporterski odpowiedzialna była tym razem Anna Hałas-Michalska, która przyjęła nieco łagodniejszy ton niż jej poprzedniczka. Należy podkreślić, że w przeciwieństwie do Dobrosz-Oracz, Hałas-Michalska nie została zwolniona z TVP w wyniku rewolucji kadrowej. Odeszła na własne życzenie dopiero we wrześniu 2016 roku $^{46}$. Warto zatem pokrótce przyjrzeć się bliżej temu materiałowi, aby dostrzec różnicę w przedstawianiu praktycznie tego samego wydarzenia, dla tej samej telewizji przez dwie różne dziennikarki.

Hasła i transparenty, z którymi manifestował KOD, pozostały w zasadzie te same: „W obronie Trybunału Konstytucyjnego i demokracji”. Nie zabrakło wypowiedzi szefa KOD Mateusza Kijowskiego, byłego działacza opozycji w czasach PRL Henryka Wujca, aktorki Mai Komorowskiej czy reżyserki Agnieszki Holland. Znaczącą różnicą pomiędzy materiałem Dobrosz-Oracz a tym przygotowanym przez Hałas-Michalską było umożliwienie wypowiedzenia się przedstawicielom strony rządowej. Reporterka powołała się na stanowisko partii Prawo i Sprawiedliwość, że „fakt, iż odbywają się manifestacje, to dowód na to, że demokracja nie jest zagrożona". Zostało to następnie potwierdzone przez wypowiedź Jarosława Sellina, wiceministra kultury w rządzie PiS, który stwierdził, iż „możemy się różnić w poglądach, ale to, że z powodu publicznego przejmują się Polską, chociaż w moim przekonaniu ulegli jakiejś fałszywej propagandzie, to samo przejmowanie się Polską mnie nie martwi”. Autorka materiału twierdzi, że politycy opozycji są mniej widoczni niż tydzień temu, choć część z nich bierze udział w demonstracjach. Tuż po tej wypowiedzi na ekranie pojawia się Grzegorz Schetyna i wygłasza postulaty podobne jak przed tygodniem. Kamila Gasiuk-Pihowicz z Nowoczesnej zapewnia z kolei o swoim udziale w manifestacjach. Do głosu dopuszczony zostaje również przedstawiciel ruchu Kukiz'15, wicemarszałek Sejmu Stanisław Tyszka, który stwierdza, że: „ludzie mają prawo protestować, natomiast tam jest wiele osób o słusznych intencjach, a jednocześnie trochę naiwnych, bo dających się sterować politykom Platformy Obywatelskiej (...)”. Przez następnych kilkadziesiąt sekund Hałas-Michalska w merytoryczny sposób tłumaczy główne założenia nowego projektu nowelizacji ustawy o Trybunale Konstytucyjnym autorstwa Prawa i Sprawiedliwości, przeciw któremu w głównej mierze zorganizowane zostały manifestacje.

W kolejnej części swój komentarz wypowiada Jarosław Kalinowski, europoseł PSL, którego główna myśl zawarta jest w powiedzeniu: „Kto nie jest z nimi, ten jest przeciwko nim". Po chwili pojawia się kolejny przedstawiciel Prawa i Sprawiedliwości, wicemarszałek Senatu Adam Bielan, który stwierdza, że: „kryzys wokół

${ }^{46}$ Zob.http://www.wirtualnemedia.pl/artykul/anna-halas-michalska-odchodzi-z-wiadomosci-tvp1 (dostęp: 2.06.2017). 
Trybunału Konstytucyjnego jest spowodowany działaniem pana prezesa Rzeplińskiego i polityków Platformy i PSL-u, którzy przegłosowali niekonstytucyjną ustawę w czerwcu tego roku". W materiale reporterskim wykorzystano również wypowiedź kardynała Stanisława Dziwisza dla radia RMF FM, w której skomentował ostatnie wydarzenia słowami: „Trzeba umieć odejść z funkcji, którą się miało, a równocześnie trzeba umieć podjąć obowiązki, które się wzięło na siebie”. Materiał kończy się zwróceniem uwagi autorki na odbywającą się w Łodzi równolegle kontrmanifestację narodowców. Całość trwała nieco ponad 4 minuty.

\subsection{Protesty KOD w 35. rocznicę wprowadzenia stanu wojennego w Polsce ${ }^{47}$}

Poniższy opis będzie miał charakter porównawczy. Zestawione ze sobą zostaną materiały o tej samej tematyce, ale przedstawione z perspektywy dwóch niezależnych serwisów informacyjnych i jednocześnie dwóch największych konkurentów o uwagę widzów - Wiadomości TVP oraz Faktów TVN.

13 grudnia 2016 roku flagowy serwis informacyjny TVP1 poprowadziła Danuta Holecka. Na szczycie agendy znalazła się rocznica stanu wojennego. Twórcą pierwszego materiału reporterskiego jest Bartłomiej Graczak, który w styczniu 2016 roku przeszedł do TVP1 z TV Republika ${ }^{48}$. Materiał obfituje w wypowiedzi ekspertów i opozycjonistów. Wypowiadają się Grzegorz Majchrzak z IPN, Adam Borowski, działacz opozycji, Kazimierz Bochenek, Andrzej Michałowski, Wojciech Borowik oraz prof. Wiesław Wysocki. Prowadząca zaznacza, że ostatnim punktem obchodów był wiec zorganizowany przez Prawo i Sprawiedliwość, w którym udział wzięła premier Beata Szydło oraz prezes PiS Jarosław Kaczyński. Graczak podsumowuje wypowiedź polityka słowami: „Lider PiS wygłosił dziś mocne przemówienie, krytykując tych, którzy dzisiejszą polską rzeczywistość porównują do tej sprzed 35 lat". W kadrze pojawia się po chwili Andrzej Gwiazda, który przekonuje, że dzisiejsza opozycja ma charakter totalitarny. Zadaje pytania, czy nie powinna ona skupić się na współpracy dla dobra kraju zamiast jątrzyć.

W kolejnym materiale przedstawionym w Wiadomościach Holecka rozpoczyna zapowiedź od słów: „Swoje obchody zorganizowała też opozycja, tyle tylko, że $\mathrm{z}$ hasłami przeciwko polityce obecnego rządu, a nawet $\mathrm{w}$ obronie esbeckich emerytur”. Na dole ekranu pojawia się napis: „Marsz KOD i protest esbeków”. Prezenterka podkreśla, że marsz Komitetu Obrony Demokracji rozpoczął się pod dawną siedzibą KC PZPR i przeszedł przed siedzibę Prawa i Sprawiedliwości. Głos zostaje przekazany reporterowi Marcinowi Tulickiemu, który znajduje się w końcowym punkcie marszu.

47 Źródło: główne wydania Wiadomości TVP1 oraz Faktów TVN, 13.12.2016.

${ }^{48} \mathrm{Zob}$. http://www.wirtualnemedia.pl/artykul/bartlomiej-graczak-przeszedl-z-tv-republika-do-wiadomosci-tvp1 (dostęp: 2.06.2017). 
Reporter zaznacza, że dzień ten obfitował w manifestacje, przy czym szczególną uwagę zwraca na demonstrację zorganizowaną przez „byłych esbeków”, przeciwnych planom rządu dotyczącym obniżenia dla nich emerytur. Tulicki dodaje, że data tego protestu dla wielu jest „skandaliczna”. Reporter kontynuuje relację sprzed siedziby Prawa i Sprawiedliwości, zarzucając Komitetowi Obrony Demokracji i opozycji, że tak trudna historycznie dla Polaków data jest dziś przez nich wykorzystywana politycznie.

W kolejnej części materiału pokazane są zdjęcia z samego marszu KOD. Reporter ponownie zaznacza, że manifestacje rozpoczęły się pod byłą siedzibą KC PZPR, a zapraszał na nie między innymi przewodniczący PO Grzegorz Schetyna na swoim profilu na Twitterze. Dalej posiłkuje się własną opinią, zgodnie z którą „organizatorzy marszu uznali, że dobrą datą na antyrządowe protesty jest rocznica wprowadzenia stanu wojennego". Tulicki zarzuca byłym opozycjonistom, że idą ramię w ramię z tymi, którzy 35 lat temu byli po stronie władzy. Na potwierdzenie przytoczona zostaje wypowiedź Władysława Frasyniuka, byłego opozycjonisty, do manifestujących: „Ten masz rozpoczyna się od komitetu centralnego PZPR, [idziemy] do centralnego komitetu PiS i tam wykrzyczymy Kaczyńskiemu nasze prawa!". Dalej reporter odwołuje się do słów lidera KOD-u Mateusza Kijowskiego o wolności, „o którą dziś także trzeba walczyć”. Po chwili na ekranie wypowiadają się przypadkowi maszerujący, przy czym szczególną uwagę przyciąga kuriozalna sytuacja, gdy jeden z nich zaczyna krzyczeć do młodego reportera TVP: „Idźcie stąd! Idźcie stąd!”. Gdy reporter zadaje mu pytanie, dlaczego mają iść i dlaczego ten go dotyka, demonstrujący odpowiada: „Bo lubię! Lubię pana dotykać! My się tu wszyscy dotykamy, nikomu to nie przeszkadza”, a następnie dodaje: „Puścisz to teraz w telewizji? Kogo z nas zrobisz? Spadaj stąd!”.

W kolejnych sekundach Tulicki wspomina, że wspólnie z KOD-em maszerowali byli opozycjoniści, dla których „nie do pomyślenia jest”, że w tym dniu na ulicę wyszli także byli przedstawiciele komunistycznej władzy. Nie ma konkretnej wypowiedzi na potwierdzenie tej tezy, w tle słychać jedynie anonimowy krzyk do mikrofonu: „Cała Polska z was się śmieje, komuniści i złodzieje!”.

Dalsza część materiału skupia się na równoległym proteście przeciwko obniżeniu emerytur byłym funkcjonariuszom Służby Bezpieczeństwa. Reporter zaznacza, że niewiele osób chciało tam odpowiadać na pytania, i rzeczywiście na ekranie widać niechęć, a nawet słychać przekleństwa kierowane w stronę dziennikarza TVP. Po chwili Tulicki dodaje: „Tu nie wszyscy stan wojenny taktują jako zbrodnię” i potwierdza tę tezę wypowiedzią przypadkowej kobiety: „Ja nie wiem, ja nic nie zrobiłam zbrodniczego". Gdy pytający dziennikarz podkreśla, że około stu osób straciło wtedy życie, kobieta odpowiada: „No a teraz ile osób traci, ile dzieci traci życie? Przez to, że te 500 plus dają, rodzą te dzieci, a potem o ścianę je rozbijają".

Reporter tłumaczy następnie, że emerytury dla rozpoczynających służbę w PRL mają zostać zmniejszone do kwoty nieco ponad dwóch tysięcy złotych. Na ekranie pojawia się w tym momencie postać generała Jerzego Stańczyka, byłego 
komendanta głównego policji, który przemawia do protestujących: „Grozi nam pozbawienie podstaw do życia. Ja skończyłem 80 lat. Za dwa tysiące złotych nie jestem w stanie wyżyć". Tulicki przypomina, że dzisiejsze kwoty emerytur dla byłych esbeków to często nawet kilkanaście tysięcy złotych. Protestujący przed Sejmem byli wspierani przez polityków, m.in. Andrzeja Rozenka, wiceprzewodniczącego Biało-Czerwonych: „Myślą, że rządzą Polską. Ale to jest chwilowe i przejściowe (...) i w tym jest nadzieja".

W ostatniej części materiału akcja przenosi się do Sejmu, gdzie w tym samym czasie politycy Platformy Obywatelskiej spotkali się z Lechem Wałęsą. Pokazana zostaje wspólna konferencja prasowa Schetyny i Wałęsy. Reporter ostatecznie kończy swój materiał słowami odnoszącymi się do poprzednich prezydentów Polski, jednocześnie wypominając im przeszłość: „Lech Wałęsa i politycy opozycji wiele dziś mówili o pamięci ofiar stanu wojennego, ale w 2014 roku dwaj byli prezydenci i urzędujący wówczas Bronisław Komorowski wzięli udział w pogrzebie ostatniego komunistycznego dyktatora, odpowiedzialnego za wprowadzenie stanu wojennego Wojciecha Jaruzelskiego". Materiał Marcina Tulickiego wraz z jego wejściem „na żywo" po zapowiedzi prezenterki trwał niespełna 6 minut.

Fakty TVN skupily się w tym dniu w pierwszym materiale reporterskim na wiecu zorganizowanym przez Prawo i Sprawiedliwość. Prowadząca Justyna Pochanke rozpoczęła serwis słowami: „Trzynasty grudnia na ulicach Warszawy to smutny dzień, dramatyczny podział, ale imponująca liczba ludzi, którzy wyszli na ulicę, bo sytuacja nie jest im obojętna”. Prezenterka zapowiedziała relację z marszu KOD, wcześniej jednak oddała głos Krzysztofowi Skórzyńskiemu, znajdującemu się na wiecu Prawa i Sprawiedliwości. Przez kilka sekund w tle za reporterem można usłyszeć pieśn Jana Pietrzaka Żeby Polska była Polską, do której po chwili odnosi się Skórzyński, podkreślając, że jest to już „tradycyjny element wszystkich demonstracji Prawa i Sprawiedliwości”. Dziennikarz relacjonuje także wystąpienie Andrzeja Gwiazdy, który mówił o stanie wojennym, transformacji, „ale” (przy czym owo „ale” zostało wyraźnie zaakcentowane przez dziennikarza) komentował też bieżące wydarzenia polityczne, funkcjonowanie Komitetu Obrony Demokracji i zorganizowany przez KOD marsz, co zdaniem Skórzyńskiego stanowiło dopełnienie najważniejszego, kulminacyjnego przemówienia na demonstracji Prawa i Sprawiedliwości, czyli przemówienia prezesa Jarosława Kaczyńskiego. Reporter zauważa, że na samym początku przemówienia Kaczyńskiego była co prawda krótka wypowiedź na temat ofiar stanu wojennego, jednak zdecydowaną większość czasu zajął „bardzo długi, bardzo polityczny, bardzo bieżący fragment”. Przez następne 60 sekund na ekranie pokazywany jest fragment wypowiedzi Jarosława Kaczyńskiego, który mówi między innymi o korzyściach płynących dla zwolenników poprzedniego systemu i ich pozycjach oraz o próbach „zanurzania polskiego społeczeństwa we mgle absurdu" poprzez porównywanie obecnych rządów i obecnej sytuacji politycznej do czasów PRL. Na ekran powraca reporter, który podsumowuje ukazany fragment jako clou wypowiedzi Kaczyńskiego i kończy swoje wejście wypowiedzią 
mającą po części charakter opinii: „Dla prezesa Prawa i Sprawiedliwości wszystkie demonstracje Prawa i Sprawiedliwości pełnią funkcję bardzo polityczną, mobilizującą elektorat, to z tych scen zawsze na demonstracjach Prawa i Sprawiedliwości płyną bieżące komunikaty do elektoratu”. Na koniec Skórzyński podkreśla, że tym razem nie jest to marsz, lecz stacjonarna demonstracja zwolenników PiS. Cały materiał trwał niespełna 3 minuty.

O marszu zorganizowanym przez Komitet Obrony Demokracji Fakty poinformowały w następnym materiale. Prowadząca rozpoczęła jego zapowiedź, cytując słowa lidera KOD-u Mateusza Kijowskiego: „Wtedy odebrali nam wolność, dziś nie damy jej sobie zabrać”. Przywołała również cytowane wcześniej słowa Władysława Frasyniuka. Na ekranie pojawił się w tym momencie Paweł Płuska, znajdujący się w centrum manifestacji zorganizowanej przez KOD. Zwracając się do dziennikarza, Pochanke użyła sformułowania, iż „to jest marsz mniej ku pamięci (...), ale bardziej ku przestrodze....”.

„Oczywiście ku przestrodze, by nie powtórzyło się to, co wydarzyło się 35 lat temu" - doprecyzowuje myśl prowadzącej Paweł Płuska. Reporter zwraca uwagę, że tak jak przed chwilą u Krzysztofa Skórzyńskiego na scenie był Jarosław Kaczyński, tak na marszu KOD-u był Władysław Frasyniuk, który apelował o to, aby się nie bać tego dnia. Następnie zaakcentowane zostało, że marsz przeszedł „od domu partii do domu partii”, czyli od dawnej siedziby PZPR do obecnej siedziby PiS i był prowadzony przez polityków i liderów KOD-u. W tym momencie pokazana zostaje wypowiedź Kijowskiego, a tuż po niej Ewy Kopacz, która stwierdziła, że „Jarosław Kaczyński zawłaszczył sobie to państwo (...) i myśli, że mu to ujdzie płazem”.

Na ekranie ponownie pojawia się Paweł Płuska i kontynuuje swoją relację. Przypomina, że dzisiejszy marsz odbył się pod hasłem „Stop dewastacji Polski” i obecnie trwa strajk obywatelski. Reporter wymienia postulaty, wśród których jest odwołanie rządu Beaty Szydło czy wstrzymanie reformy edukacji, jednak główną konkluzję wyraża słowami: „Oni mówili, że mają dość tego, co się dzieje. Chcą innej Polski - lepszej Polski”. Autor materiału przytacza po chwili wypowiedzi czterech przypadkowych osób, które również w tym miejscu zacytuję, aby czytelnik mógł sam odpowiedzieć na pytanie, czy rzeczywiście potwierdzają one wniosek reportera:

- „Można zdewastować państwo w jeden rok, ale będziemy odbudowywali kolejne 20 lat. Nie wolno się na to zgadzać”.

- „My pamiętamy, że mieliśmy wolność przez 27 lat i chcemy, żeby nasze dzieci też to miały".

- „Dla nas to jest tak bolesna rocznica i tak jest łamane w tej chwili w dalszym ciągu prawo, że powinniśmy zaprotestować".

- „Nie mogę tu nie być. Jestem tu z przyjaciółmi. Jedno mamy marzenie wspólne - wolna, demokratyczna Polska, i dlatego musimy tu być”.

Pod koniec materiału reporter zwraca uwagę, że w trakcie marszu demonstracja KOD spotkała się z „kontrmanifestacją” zorganizowaną przez zwolenników PiS. 
Na szczęście doszło tylko do utarczek słownych, co zdaniem Płuski było zasługą sprawnego działania policji. W ostatnim zdaniu reporter pokusił się o osobistą refleksję: „Jak patrzyłem na to wszystko, to było trochę przykro, że tego dnia znowu naprzeciwko siebie stanęli Polacy - jedni i drudzy trzymający w rękach biało-czerwoną”. Trzyminutowy materiał Justyna Pochanke podsumowała słowami: „Bitwa na słowa i argumenty, na szczęście bitwa bez ofiar, czyli esencja demokracji”.

\subsection{XXIII i XV Finał Wielkiej Orkiestry Świątecznej Pomocy ${ }^{49}$}

Chyba najbardziej jaskrawym przykładem wpływu zmiany otoczenia politycznego na zarządzanie informacją w Wiadomościach TVP jest kwestia Wielkiej Orkiestry Świątecznej Pomocy. Finał WOŚP nie jest co prawda wydarzeniem politycznym, ale bacznie obserwując przebieg zdarzeń, można pokusić się o stwierdzenie, że niejako padł on ofiarą politycznych sympatii lub może bardziej antypatii. Poniżej opisane zostały dwie relacje dotyczące finału WOŚP - z 11 stycznia 2015 roku, czyli na długo przed wymianą kadrową w TVP, oraz z 15 stycznia 2017 roku, czyli już po ugruntowaniu się nowej załogi. Wydarzenia te celowo zostały ze sobą zestawione $\mathrm{w}$ jednym podrozdziale, aby łatwiej dostrzec zmianę w ich przekazie. Przypadek ten jest o tyle ciekawszy, że oba wydania flagowego serwisu informacyjnego TVP1, w którym poruszono tematykę WOŚP, poprowadził Krzysztof Ziemiec, do dziś współpracujący z Telewizją Polską.

„Koncerty, pokazy, licytacje, biegi, rajdy, no i setki innych atrakcji, a przede wszystkim uliczne kwesty prowadzone przez wolontariuszy" - w ten sposób Ziemiec z pogodnym wyrazem twarzy zapowiada materiał dotyczący XXIII Finału Wielkiej Orkiestry Świątecznej Pomocy w 2015 roku. Prowadzący zwraca uwagę na to, jak spożytkowane zostaną pieniądze zebrane podczas tegorocznego finału, po czym oddaje głos twórcy materiału, Marcinowi Szewczakowi.

Reporter rozpoczyna program od ukazania historii Karoliny z Gorzowa Wielkopolskiego, która zawdzięcza swoje życie sprzętowi zakupionemu ze środków Wielkiej Orkiestry. Na ekranie pojawia się matka zastępcza dziewczyny, która mówi, że dzieci takie jak Karolina mają takie samo prawo do życia jak inni. Następnie oczom widza ukazują się kolejne dzieci - czteroletnia Wiktoria i ośmiomiesięczny Kacper. Reporter zwraca uwagę na fakt, że oboje urodzili się za wcześnie, jednak „orkiestrowy sprzęt pomógł im nadrobić zaległości i dziś są zdrowe”. Matka dzieci podkreśla, że nigdy nie wiadomo, kiedy ktoś będzie potrzebował pomocy WOŚP, zatem każdy może mieć w tym kiedyś swój udział. W kadrze pojawia się charakterystyczna skarbonka, a reporter stwierdza, że wszystko zaczyna się od „symbolicznej złotówki”. Przez kilkanaście sekund wypowiadają się przypadkowi przechodnie, zapewniając o swoim wsparciu dla akcji prowadzonej przez WOŚP. Następnie autor materiału

49 Źródło: główne wydania Wiadomości TVP1, 11.01.2015 i 15.01.2017. 
płynnie przechodzi do kwestii samego pomagania, podkreślając, że „razem możemy więcej", co potwierdzają wypowiadający się wolontariusze.

Mija połowa materiału. Pojawia się melodia charakterystyczna dla Wielkiej Orkiestry Świątecznej Pomocy, w tle można dostrzec radosnych ludzi zgromadzonych na finale oraz twarz Jerzego Owsiaka. W tym samym momencie reporter wyjaśnia, dla kogo Orkiestra gra w tym roku. W tle słychać nostalgiczną muzykę, na ekranach widać twarze chorych dzieci oraz seniorów. Szewczak zwraca uwagę na zaniedbane oddziały geriatryczne, które często również potrzebują pomocy. Andrzej Jóźwiak, ordynator oddziału geriatrii z Wojewódzkiego Szpitala dla Nerwowo i Psychicznie Chorych w Gnieźnie, zaznacza, że dzięki pomocy WOŚP placówka otrzymała „duży zastrzyk nowego sprzętu”.

Po raz kolejny w kadrze ukazują się skarbonki WOŚP, w tle rozbrzmiewa charakterystyczna, radosna melodia, a od reportera dowiadujemy się o możliwości licytacji przedmiotów przekazanych przez artystów i sportowców. Głos zostaje oddany samemu Jerzemu Owsiakowi, który z charakterystycznym dla siebie entuzjazmem wymienia inne, możliwe do wylicytowania atrakcje.

Pod koniec materiału mamy kolejną wypowiedź Owsiaka, który mówi, jak wielkim zaskoczeniem i niedowierzaniem dla ludzi na całym świecie jest zrodzona w Polsce chęć do wspólnego grania, przebywania ze sobą i pokazania, że „dzięki temu możemy zrobić rzeczy niebywałe”. Myśl Owsiaka kończy reporter: „I robimy - dla innych, ale także dla siebie”.

Nieco ponad dwa lata później w głównym wydaniu Wiadomości prowadzonym ponownie przez Krzysztofa Ziemca nie było dużego, oddzielnego materiału reporterskiego poświęconego Wielkiej Orkiestrze. Jedynie na sam koniec wydania prowadzący podał czternastosekundowy komunikat o następującej treści: „Trwa XXV Finał Wielkiej Orkiestry Świątecznej Pomocy. Zebrane fundusze wspomogą zakup sprzętu do szpitalnych oddziałów ogólnopediatrycznych i geriatrycznych. Do tej pory wolontariusze zebrali ponad 22 miliony złotych". Po tej wypowiedzi snuto domysły, że mogła być ona zainicjowana przez samego Ziemca, bo gdy prezenter schodził z anteny ze słowami: „To były Wiadomości”, jego wypowiedź niespodziewanie została przerwana przez dżingiel ${ }^{50}$.

Niespełna dwa miesiące później, 7 marca 2017 roku Jerzy Owsiak ogłosił pełną kwotę, jaką udało się zebrać podczas ostatniego finału WOŚP. Pobito wtedy absolutny rekord - 105 milionów złotych, czyli o 33 miliony więcej niż w roku poprzednim. Główne wydanie Wiadomości poprowadziła w tym dniu Danuta Holecka. O zebranej kwocie tym razem nie było ani słowa.

${ }_{50}$ Zob. http://www.newsweek.pl/polska/wosp-zebrala-rekordowe-105-mln-zl-a-w-wiadomosciach-jedno-zdanie,artykuly,406547,1.html (dostęp: 2.06.2017). 


\section{Podsumowanie}

Telewizja Polska to organizacja medialna, która zgodnie z zasadą działania mediów publicznych jest w całości kontrolowana przez państwo. Jej funkcjonowanie jest uzależnione w największym stopniu od otoczenia politycznego, a ściślej - od idei reprezentowanych przez będącą u władzy partię lub koalicję. Nie jest zatem niczym nadzwyczajnym, że każda nowa władza będzie dążyć do podporządkowania sobie publicznej telewizji i stworzenia z niej swoistego pośrednika między partią będącą u władzy a społeczeństwem.

Zgodnie z nurtem zarządzania humanistycznego podstawową jednostką budującą każdą organizację jest człowiek. Nie inaczej jest w przypadku Telewizji Polskiej. Ze względu jednak na specyfikę funkcjonowania tej organizacji medialnej pracujący tam dziennikarze są najczęściej narzędziami w rękach władzy, dzięki którym może ona prowadzić swoją politykę w sposób sprawny i skuteczny. Wiąże się to również z możliwością przeprowadzenia przez rząd gruntownej rekonstrukcji kadrowej i zastąpienia dotychczasowych pracowników nowymi, bardziej przychylnymi danej partii lub podzielającymi jej linię programową. Taka właśnie rewolucja kadrowa nastąpiła w Telewizji Polskiej na początku 2016 roku za sprawą działań nowego rządu, wyłonionego $\mathrm{w}$ wyborach parlamentarnych niespełna trzy miesiące wcześniej.

Zwycięstwo Prawa i Sprawiedliwości zapewniło tej partii liczbę mandatów wystarczającą do samodzielnego rządzenia. Jednym z jej głównych punktów programowych była „naprawa mediów publicznych”. Mało kto spodziewał się, że ta naprawa rozpocznie się od tak gwałtownej rewolucji kadrowej, gdzie w wyniku masowych zwolnień odejdą dziennikarze posiadający nie tylko wieloletnie doświadczenie, ale też rangę „liderów opinii”, jak Piotr Kraśko czy Maciej Orłoś. Ich miejsca zaczęli wypełniać inni - niektórzy nowi, a niektórzy odsunięci od pracy przez poprzednią władzę, jak na przykład Danuta Holecka.

Szczególnie zauważalna zmiana dotknęła Wiadomości TVP1. Wymiana pojawiającego się w tle za gospodarzem serwisu zegara z Pałacu Kultury i Nauki na zegar z Zamku Królewskiego w Warszawie była symboliczną zapowiedzią nadchodzących „nowych czasów”. Nowy wydźwięk informacji o charakterze politycznym zaczął z każdym dniem stawać się coraz bardziej zauważalny.

Przedstawione w niniejszym artykule badania empiryczne na podstawie analizy wybranych wydarzeń przedstawionych $\mathrm{w}$ Wiadomościach pozwoliły na potwierdzenie tezy o istnieniu wpływu wymiany kadrowej na zarządzanie informacją. Różnice między przekazami w telewizji publicznej przed i po zmianach kadrowych wyrażają się w różnej formie: poprzez dobór informacji, ich miejsce w programie, formę prezentacji samej informacji i jej treści. Są także widoczne w zestawieniu $\mathrm{z}$ informacjami komercyjnej stacji TVN.

Pierwszy przykład, dotyczący manifestacji KOD związanych z kryzysem wokół Trybunału Konstytucyjnego, pokazuje, że wydźwięk danego przekazu jest bardzo 
często uzależniony od samego twórcy materiału. Zarówno Justyna Dobrosz-Oracz, jak i Anna Hałas-Michalska relacjonowały bardzo podobne wydarzenia, oddalone od siebie w czasie zaledwie o tydzień. Co więcej, obie pracowały dla organizacji zarządzanej jeszcze w tym czasie przez ludzi z nadania poprzedniej władzy. Mimo to oba przekazy zostały skonstruowane różnie co do formy, treści i innych elementów perswazyjnych przekazu informacyjnego.

Zdecydowaną różnicę można dostrzec podczas analizy podobnego wydarzenia, które rozegrało się dokładnie rok później. Porównując relację z protestów zorganizowanych przez Komitet Obrony Demokracji w 35. rocznicę wprowadzenia stanu wojennego $\mathrm{z}$ materiałami sprzed roku, zmiana $\mathrm{w}$ sposobie konstruowania i w wydźwięku przekazu wydaje się oczywista. Całości dopełnia zestawienie relacji dotyczącej tego wydarzenia z perspektywą zaproponowaną przez Fakty TVN. Nie zamierzam oceniać tutaj poziomu stronniczości obu przekazów - pozostawiam to indywidualnej ocenie czytelnika. Nie można jednak oprzeć się wrażeniu, że po obejrzeniu materiałów w obu serwisach rodzi się poczucie uczestnictwa w dwóch odmiennych rzeczywistościach.

Najbardziej jaskrawy przykład zmiany, jaka nastąpiła w przekazie płynącym z Wiadomości, pozostawiłem na koniec. Jak już wcześniej wspomniałem, finał Wielkiej Orkiestry Świątecznej Pomocy nie jest wydarzeniem stricte politycznym, ale został niejako do tej polityki wciągnięty. Obszerną relację reporterską z 2015 roku zestawiono z krótkim komunikatem przekazanym na sam koniec Wiadomości przez tego samego prezentera.

Na zakończenie warto ponownie podkreślić, że obsadzanie stanowisk w Telewizji Polskiej ludźmi podążającymi w kierunku zgodnym z linią programową partii rządzącej nie jest zjawiskiem nowym i najpewniej będzie praktykowane za każdym razem, gdy władzę w kraju będą obejmować kolejne ugrupowania. Wciąż otwarta pozostaje jednak kwestia zachowania dziennikarskiej obiektywności i bezstronności - zarówno w mediach publicznych, jak i komercyjnych.

\section{Bibliografia}

Albarran A.B., Management of Electronic and Digital Media, Wadsworth Thomson Learning, Belmont, CA 2002.

Brilman J., Nowoczesne koncepcje i metody zarządzania, przeł. K. Bolesta-Kukułka, PWE, Warszawa 2002.

Drucker P.F., Praktyka zarządzania, przeł. T. Basiuk, Z. Broniarek, J. Gołębiowski, Wydawnictwo MT Biznes, Warszawa 2008.

Kowalski T., Między twórczością a biznesem, Wydawnictwa Akademickie i Profesjonalne, Warszawa 2008.

Koźmiński A.K., Piotrowski W. (red.), Zarzq̨dzanie. Teoria i praktyka, Wydawnictwo Naukowe PWN, Warszawa 1997. 
Mrozowska M., Media masowe. Władza, rozrywka i biznes, Oficyna Wydawnicza ASPRA-JR, Warszawa 2001.

Nierenberg B., Zarządzanie mediami. Ujęcie systemowe, Wydawnictwo Uniwersytetu Jagiellońskiego, Kraków 2011.

Picard R.G., Media Economics: Concepts and Issues, Sage Publications, Thousand Oaks, CA 1989.

Różycka M., Zarządzanie zasobami ludzkimi w mediach publicznych. Studium przypadku TVP Katowice, „Zarządzanie Mediami” 2016, nr 4 (2).

Sajkiewicz A. (red.), Jakość zasobów pracy. Kultura, kompetencje, konkurencyjność, Poltext, Warszawa 2002.

\section{Źródła internetowe:}

Adrian Klarenbach po trzech latach wraca do TVP Info, http://www.wirtualnemedia.pl/artykul/ adrian-klarenbach-po-trzech-latach-wraca-do-tvp-info (dostęp: 8.04.2017).

Anna Hałas-Michalska odchodzi z „Wiadomości” TVP1, http://www.wirtualnemedia.pl/artykul/anna-halas-michalska-odchodzi-z-wiadomosci-tvp1 (dostęp: 2.06.2017).

Bartłomiej Graczak przeszedł z TV Republika do „Wiadomości” TVP1, http://www.wirtualnemedia.pl/artykul/bartlomiej-graczak-przeszedl-z-tv-republika-do-wiadomosci-tvp1 (dostęp: 2.06.2017).

Danuta Holecka wraca do prowadzenia „Wiadomości” TVP1, http://www.wirtualnemedia.pl/ artykul/danuta-holecka-wraca-do-prowadzenia-wiadomosci-tvp1 (dostęp: 8.04.2017).

Diana Rudnik po 10 latach odchodzi z TVP Info, http://www.wirtualnemedia.pl/artykul/diana-rudnik-po-10-latach-odchodzi-z-tvp-info\# (dostęp: 8.04.2017).

Ewa Godlewska-Jeneralska zwolniona $z$ TVP, http://wiadomosci.onet.pl/kraj/ewa-godlewska-jeneralska-zwolniona-z-tvp/dvm5n1 (dostęp: 8.04.2017).

Hanna Lis zwolniona $z$ „Panoramy” TVP2, http://www.wirtualnemedia.pl/artykul/hanna-lis-zwolniona-z-panoramy-tvp2 (dostęp: 8.04.2017).

Joanna Osińska po 23 latach kończy pracę $w$ Telewizji Polskiej, http://www.wirtualnemedia.pl/artykul/joanna-osinska-po-23-latach-konczy-prace-w-telewizji-polskiej(dostęp: 8.04.2017).

Karolina Lewicka odchodzi z Telewizji Polskiej, http://www.wirtualnemedia.pl/artykul/karolina-lewicka-odchodzi-z-telewizji-polskiej (dostęp: 8.04.2017).

Kolejni dziennikarze zwolnieni $z$ TVP, nowi prezenterzy. Zmiany w telewizji [KTO STRACIE PRACE LISTA], http://www.polskatimes.pl/artykul/9289275,kolejni-dziennikarze-zwolnieni-z-tvp-nowi-prezenterzy-zmiany-w-telewizji-kto-stracil-prace-lista,id,t.html (dostęp: 8.04.2017).

Maciej Orłoś odchodzi z „Teleexpressu”. Michał Cholewiński nowym prowadzacym, http://businessinsider.com.pl/media/maciej-orlos-odchodzi-z-teleexpressu-tvp/wy4lh4j (dostęp: 8.04.2017).

Michał Adamczyk wraca do głównego wydania „Wiadomości” TVP1, http://www.wirtualnemedia.pl/artykul/michal-adamczyk-wraca-do-glownego-wydania-wiadomosci-tvp1 (dostęp: 8.04.2017).

NOWE TWARZE „WIADOMOŚCI”, http://fakty.interia.pl/polska/news-nowe-twarze-wiadomosci,nId,1953622,nPack,1 (dostęp: 8.04.2017).

Piotr Kraśko i Karolina Lewicka odchodza z TVP. Beata Tadla i Diana Rudnik odsunięte od „Wiadomości”, http://www.polskatimes.pl/artykul/9280595,piotr-krasko-i-karolina-lewicka-odchodza-z-tvp-beata-tadla-i-diana-rudnik-odsuniete-od-wiadomosci,id,t.html (dostęp: 8.04.2017). 
Profil Beaty Tadli na Facebooku, https://www.facebook.com/beata.tadla.3/posts/1201382883 211217 (dostęp: 8.04.2017).

Profil Piotra Kraśki na Twitterze, https://twitter.com/pkrasko (dostęp: 8.04.2017).

„Wiatr zmian” w TVP Jacka Kurskiego. Kto odszedt, kto przyszedt?, http://www.wirtualnemedia.pl/artykul/wiatr-zmian-w-tvp-jacka-kurskiego-kto-odszedl-kto-przyszedl\# (dostęp: 8.04.2017).

WOŚP zebrała rekordowe $105 \mathrm{mln} z$. W „Wiadomościach” ani zdania na ten temat, http://www. newsweek.pl/polska/wosp-zebrala-rekordowe-105-mln-zl-a-w-wiadomosciach-jedno-zdanie,artykuly,406547,1.html (dostęp: 2.06.2017). 